\title{
INFLUENCE OF DRAINAGE METHODS ON SOYBEAN DEVELOPMENT IN LOWLANDS
}

\author{
Ricardo B. Rosso ${ }^{1 *}$, Marcia X. Peiter ${ }^{2}$, Adroaldo D. Robaina ${ }^{2}$, Luis H. Bahú Ben², \\ Wellington Mezzomo
}

${ }^{1 *}$ Corresponding author. Instituto Federal Catarinense (IFC)/ Concórdia - SC, Brasil.

E-mail: ricardo.rosso@ifc.edu.br | ORCID ID: https://orcid.org/0000-0001-5142-1719

\section{KEYWORDS}

ridge, Glycine max, lowland.

\begin{abstract}
The need for crop rotation and profitability in lowland areas are the two main reasons for the introduction of soybean cultivation in the state of Rio Grande do Sul, Brazil. These areas have poor natural drainage, which impedes proper soybean growth. In this sense, this study aimed to assess the efficiency of using broad base ridges in comparison to the surface drainage for soybean cultivation in lowlands. The study was conducted during the 2014/2015 and 2015/2016 growing seasons in São João do Polêsine, RS, Brazil. The assessed drainage methods were the use of broad base ridges with different width dimensions $(22.5,15.0$, and $7.5 \mathrm{~m})$ and surface drainage. The results showed that the shoot dry matter and leaf area index have similar behavior. The broad base ridge was better than the surface drainage method for these variables. The $7.5-\mathrm{m}$ broad base ridge stood out among the treatments when compared to the others, as it had the best results for the leaf area index (8.66), plant height $(102.5 \mathrm{~cm})$, and shoot dry matter $(33.06 \mathrm{~g})$.
\end{abstract}

\section{INTRODUCTION}

Lowland areas in the state of Rio Grande do Sul, Brazil, which are traditionally used for irrigated rice cultivation. According to Missio et al. (2010), the monoculture of irrigated rice has predominated in these areas due to soil inhospitality for species not adapted to flooded environments. Nevertheless, according to Bortoluzzi et al. (2017), there is currently an expansion of soybean cultivation in these areas mainly due to the possibility of controlling the red rice through crop rotation. Similarly, Thomas \& Lange (2014) stated that soybean cultivation has presented a high growth in lowland areas due to two factors: the use of rice and soybean rotation as a tool for weed control and high remuneration that farmers have received for this oilseed. This optimism is perceived when observing the data from the Instituto Riograndense do Arroz (2019), which show that soybean cultivation in rotation with rice in lowland areas has been showing strong growth in the last growing seasons, with an area of 11,150 hectares in the 2009/10 season and 312,105 hectares in the 2018/19 season.

According to Bamberg et al. (2009), the main predominant soil class in lowland areas in the state of Rio Grande do Sul is the Planosol. Alves et al. (2002) reported that this soil class has poor natural drainage, which, associated with the occurrence of high precipitations, may lead to hypoxia or anoxia. Sartori et al. (2015) pointed out that stress could occur on plants due to lack of oxygen due to excess water conditions, compromising their agronomic performance. Thus, according to SOSBAI (2012), the first step for the successful implementation of soybean cultivation is the efficient drainage of the area. Agricultural drainage can be defined by a set of techniques and practices to remove excess water from the soil, mainly to ensure root aeration (Duarte et al., 2015). Similarly, Silva \& Parfitt (2004) stated that only by improving surface drainage, it is possible to provide favorable conditions for the agricultural cultivations usual in highlands.

Currently, farmers have been using surface drains for soybean cultivation in these areas, but with no good results due to their low efficiency. Thus, there is another alternative for the drainage of these soils, the broad base ridge. According to Fiorin et al. (2009), the use of ridges would be an alternative to obtain yields closer to the crop potential due to good soil aeration of in this technique. In the same region of study, Sartori et al. (2015) obtained yields of 4,345 and $4,013 \mathrm{~kg} \mathrm{ha}^{-1}$ of soybean grown on micro-ridges in Planosols in the 2013/2014 and 2014/2015 growing season, respectively.

\footnotetext{
${ }^{2}$ Universidade Federal de Santa Maria/ Santa Maria - RS, Brasil.

Area Editor: Alexandre Barcellos Dalri

Received in: 11-24-2017

Accepted in: 12-4-2019
} 
Thus, it is necessary to evaluate the performance of different drainage techniques for soybean cultivation. This study aimed to evaluate the growth and harvest index of soybean cultivars submitted to different drainage techniques: broad base ridges and surface drainage.

\section{MATERIAL AND METHODS}

The experimental area where the studies were carried out is located in the municipality of São João do Polêsine, whose geographical coordinates are $29^{\circ} 35^{\prime} 52^{\prime \prime} \mathrm{S}$ and $53^{\circ} 27^{\prime} 50^{\prime \prime} \mathrm{W}$, with an altitude of approximately $53 \mathrm{~m}$. The soil belongs to the mapping unit Vacacaí (Klamt, 1997), and it is classified as a typic Albaqualf. According to Alvares et al. (2013), the regional climate is Cfa, according to Köppen classification.

The study was conducted during the 2014/15 and
2015/16 growing seasons. The experimental area of study, before the study was set up, was occupied by rice cultivation from November to April, remaining under fallow the rest of the year.

The experiment used a randomized block design in a two-factor scheme, strip for factor A and strip for factor D, distributed within four blocks, totaling thirty-two experimental units. Factor A consisted of different drainage techniques, while factor D consisted of soybean cultivars.

The different drainage techniques consisted of broad base ridges and surface drainage. Broad base ridges had widths of 7.5, 15.0, and $22.5 \mathrm{~m}$, with slopes of $6.6,3.2$, and $1.8 \%$, respectively, to establish the ridge spacing. This slope was determined from the central point of the ridge to the drain and served to allow the displacement of water from any point of the ridge to the drainage channel, as shown in

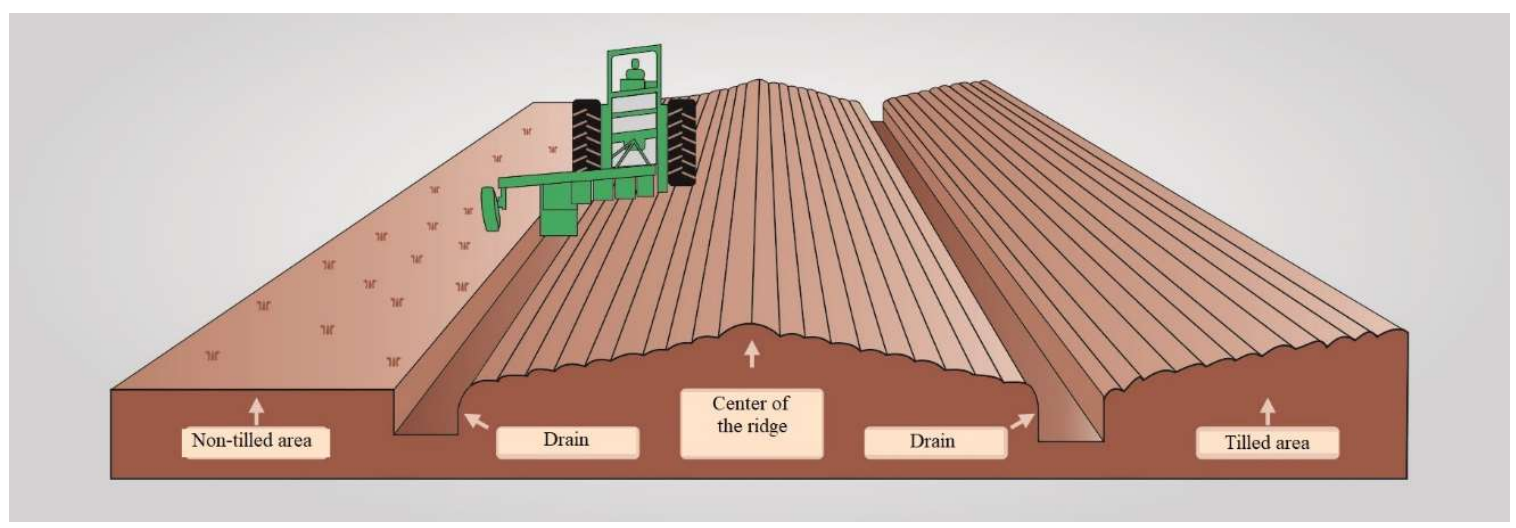

Source: Smedema \& Rycroft (1983), Beauchamp (1952), Sevenhuijsen (1994) apud Silva et al. (2006). Adapted by the authors.

FIGURE 1. The spacing between ridges, which corresponds to the drains, was $0.5 \mathrm{~m}$.

Surface drainage, a technique widely used by farmers, was used with a width of $22.5 \mathrm{~m}$ between drainage channels. The maximum slope found in this treatment was $0.1 \%$, maintaining the original characteristics of soil systematization. Soil level difference within the plot and the base value was $0.2 \mathrm{~m}$ of depth and $0.4 \mathrm{~m}$ of spacing.

The used cultivars were BMX Potência RR and TEC IRGA 6070 RR. The population density was adjusted shortly after crop establishment at 18 plants $\mathrm{m}^{-2}$ in the 2014/15 growing season and 24 plants $\mathrm{m}^{-2}$ in the $2015 / 16$ growing season. Soil fertility management and phytosanitary treatments complied with the technical recommendations for soybean cultivation (Oliveira \& Da Rosa, 2014).

During crop development, the leaf area index was evaluated at the phenological stages V3, V9, R1, R3, and $\mathrm{R} 5$, plant dry matter and plant height were evaluated at V3, V9, R1, R3, R5, and R8, and harvest index was evaluated at R8 (Fehr \& Caviness, 1977). The leaf area index was determined with a CID Bio-Science CI-203 portable leaf area meter. The leaf area index was calculated from three plants randomly collected within the experimental unit. The experimental units had $15 \mathrm{~m}^{2}$ of useful area for plant collection, which covered the entire width of the ridges and/or surface drainage.

The results were subjected to the assumption tests (normality and homogeneity of variances) and the data that did not meet the assumptions were transformed by the equation $y t=\sqrt{y}$ in order to normalize their distribution.
They were submitted to analysis of variance and ScottKnott test for mean comparison $(p<0.05)$ as a function of the qualitative nature of the applied treatments (soybean cultivars and drainage techniques). The statistical analysis software Sisvar was used for this procedure (Ferreira, 2011).

\section{RESULTS AND DISCUSSION}

The leaf area index, plant height, shoot dry matter, and harvest index were analyzed in order to understand better the influence of drainage methods on the growth of both soybean cultivars. Thus, the most efficient drainage method in its function of providing the best conditions for plant development and the cultivar best suited to this production system could be demonstrated. Precipitation events that occurred during the study period were also registered to understand plant development (Table 1).

Precipitation values obtained in the 2014/2015 and $2015 / 2016$ seasons show some precipitation periods above and below the climatological normal. In the 2014/2015 season, in the period from the second ten-day period of December until the second ten-day period of January, there is a precipitation period above the climatological normal, standing out the third ten-day period of December, with 175 $\mathrm{mm}$. In this same season, precipitations below the climatological normal are also observed from the second ten-day period of February to the second ten-day period of March. Thus, the $2014 / 2015$ season had two periods that may have influenced plant development. 
TABLE 1. Climatological normal and precipitation (mm) in the 2014/2015 and 2015/2016 growing seasons, São João do Polêsine, RS, Brazil.

\begin{tabular}{|c|c|c|c|c|c|c|c|c|c|}
\hline Month & \multicolumn{3}{|c|}{ November } & \multicolumn{3}{|c|}{ December } & \multicolumn{3}{|c|}{ January } \\
\hline Ten-day period & $1 \mathrm{st}$ & 2 nd & $3 \mathrm{rd}$ & $1 \mathrm{st}$ & $2 \mathrm{nd}$ & $3 \mathrm{rd}$ & $1 \mathrm{st}$ & 2nd & $3^{\text {rd }}$ \\
\hline Climatological normal & 55.5 & 32.6 & 27.9 & 51.9 & 44.5 & 41.0 & 65.0 & 33.7 & 52.3 \\
\hline $2014 / 2015$ season & & & & & 70 & 175 & 80 & 63 & 32 \\
\hline $2015 / 2016$ season & & & 0 & 57 & 68 & 166 & 39 & 0 & 71 \\
\hline Month & \multicolumn{3}{|c|}{ February } & \multicolumn{3}{|c|}{ March } & \multicolumn{3}{|c|}{ April } \\
\hline Ten-day period & $1 \mathrm{st}$ & 2nd & $3 \mathrm{rd}$ & $1 \mathrm{st}$ & $2 \mathrm{nd}$ & $3 \mathrm{rd}$ & $1 \mathrm{st}$ & 2nd & $3^{\text {rd }}$ \\
\hline Climatological normal & 44.4 & 53.1 & 29.9 & 28.9 & 57.8 & 52.6 & 26.5 & 54.7 & 38.9 \\
\hline $2014 / 2015$ season & 48 & 31 & 25 & 41 & 0 & 80 & 44 & 74 & 0 \\
\hline $2015 / 2016$ season & 13 & 75 & 21 & 70 & 54 & 123 & 53 & & \\
\hline
\end{tabular}

Two periods of precipitation above the climatological normal stood out in the 2015/2016 season. The first period occurs from the first ten-day period of December to the third 10-day period of December, which presented the highest precipitation value of the 2015/2016 season. The second period that stood out in the 2015/2016 season occurred from the first ten-day period of March until the first ten-day period of April. Thus, only precipitations above the climatological normal occur in this season. However, a period of high and another of low precipitations occurred in the 2014/2015 season compared to the climatological normal. This information will be used to understand better the results.

The leaf area index for the 2014/2015 and 2015/2016 growing seasons are shown in Table 2. In the 2014/2015 season, no significant difference was observed between drainage methods. Among the cultivars, a difference was observed only at the phenological stage V3, in which BMX
Potência RR was superior to TEC IRGA 6070 RR. The maximum value in the mean of treatments of the leaf area index was $4.88 \mathrm{~m}^{2} \mathrm{~m}^{-2}$, found at the $\mathrm{R} 3$ stage.

This result is lower than that observed by Richter et al. (2014), who found maximum values of leaf area index of $6.5 \mathrm{~m}^{2} \mathrm{~m}^{-2}$ for the cultivar BMX Potência RR. Given this remarkable difference, it is possible to consider that periods with precipitation above and below the climatological normal that occurred during plant development negatively influenced the leaf area index in the 2014/2015 season.

In the 2015/16 season, the drainage methods presented a statistical difference at V3, V9, R1, and R5 stages. No statistical difference was observed between cultivars at the evaluated stages. At the phenological stage $\mathrm{V} 3$, in the 2015/2016 season, the group formed by broad base ridges of 15 and $7.5 \mathrm{~m}$ was superior to the group formed by broad base ridges of $22.5 \mathrm{~m}$ and surface drainage, in the source of variation drainage.

TABLE 2. Leaf area index $\left(\mathrm{m}^{2} \mathrm{~m}^{-2}\right)$ at different phenological stages as a function of drainage techniques and soybean cultivars in the 2014/15 and 2015/16 growing seasons, São João do Polêsine, RS, Brazil.

\begin{tabular}{|c|c|c|c|c|c|}
\hline Treatment & V3 & V9 & $\mathrm{R} 1$ & R3 & R5 \\
\hline & \multicolumn{5}{|c|}{$2014 / 2015$ growing season } \\
\hline Surface drainage & $0.16 \mathrm{a}$ & $0.99 \mathrm{a}$ & $2.43 \mathrm{a}$ & $3.64 \mathrm{a}$ & $0.92 \mathrm{a}$ \\
\hline Broad base ridge of $22.5 \mathrm{~m}$ & $0.21 \mathrm{a}$ & $1.25 \mathrm{a}$ & $2.88 \mathrm{a}$ & $3.96 \mathrm{a}$ & $1.26 \mathrm{a}$ \\
\hline Broad base ridge of $15 \mathrm{~m}$ & $0.21 \mathrm{a}$ & $2.08 \mathrm{a}$ & $3.47 \mathrm{a}$ & $4.65 \mathrm{a}$ & $1.35 \mathrm{a}$ \\
\hline Broad base ridge of $7.5 \mathrm{~m}$ & $0.23 \mathrm{a}$ & $1.74 \mathrm{a}$ & $3.65 \mathrm{a}$ & $4.88 \mathrm{a}$ & $1.74 \mathrm{a}$ \\
\hline $\mathrm{CV}(\%)$ & $11.51 *$ & $32.14 *$ & $35.71 *$ & $14.98 *$ & $27.53 *$ \\
\hline BMX Potência RR & $0.24 \mathrm{~b}$ & $1.56 \mathrm{a}$ & $3.18 \mathrm{a}$ & $4.74 \mathrm{a}$ & $1.53 \mathrm{a}$ \\
\hline TEC IRGA 6070 RR & $0.171 \mathrm{a}$ & $1.47 \mathrm{a}$ & $3.04 \mathrm{a}$ & $3.83 \mathrm{a}$ & $1.11 \mathrm{a}$ \\
\hline $\mathrm{CV}(\%)$ & $12.51 *$ & $10.28 *$ & $12.89 *$ & $13.47 *$ & $12.02 *$ \\
\hline \multirow[t]{2}{*}{ Overall mean } & 0.203 & 1.519 & 3.108 & 4.28 & 1.32 \\
\hline & \multicolumn{5}{|c|}{ 2015/2016 growing season } \\
\hline Surface drainage & $0.36 \mathrm{~b}$ & $1.3 \mathrm{~b}$ & $3.89 \mathrm{c}$ & $7.03 \mathrm{~b}$ & $4.04 \mathrm{a}$ \\
\hline Broad base ridge of $22.5 \mathrm{~m}$ & $0.37 \mathrm{~b}$ & $1.46 \mathrm{~b}$ & $4.87 \mathrm{~b}$ & $7.25 \mathrm{~b}$ & $3.68 \mathrm{a}$ \\
\hline Broad base ridge of $15 \mathrm{~m}$ & $0.47 \mathrm{a}$ & $1.65 \mathrm{~b}$ & $5.81 \mathrm{a}$ & $8.07 \mathrm{a}$ & $4.26 \mathrm{a}$ \\
\hline Broad base ridge of $7.5 \mathrm{~m}$ & $0.56 \mathrm{a}$ & $2.03 \mathrm{a}$ & $5.54 \mathrm{a}$ & $8.66 \mathrm{a}$ & $4.86 \mathrm{a}$ \\
\hline CV $(\%)$ & $13.26 *$ & 17.6 & 12.54 & 9.4 & $13.05 *$ \\
\hline BMX Potência RR & $0.46 \mathrm{a}$ & $1.56 \mathrm{a}$ & $5.01 \mathrm{a}$ & $7.74 \mathrm{a}$ & $4.39 \mathrm{a}$ \\
\hline TEC IRGA 6070 RR & $0.41 \mathrm{a}$ & $1.66 \mathrm{a}$ & $5.04 \mathrm{a}$ & $7.76 \mathrm{a}$ & $4.03 \mathrm{a}$ \\
\hline CV $(\%)$ & $11.5 *$ & 11.66 & 11.45 & 13.98 & $12.2 *$ \\
\hline Overall mean & 0.439 & 1.61 & 5.03 & 7.75 & 4.21 \\
\hline
\end{tabular}

Means followed by the same letter in the column do not differ from each other by the Scott-Knott test at $5 \%$ significance. *Data transformed. 
In the second evaluation of the 2015/2016 season, carried out at stage V9, the broad base ridge of $7.5 \mathrm{~m}$ was classified as superior to the other treatments. In the third evaluation, carried out at the phenological stage R1, the statistical analysis indicated the superiority of broad base ridges of 15.0 and $7.5 \mathrm{~m}$. The second highest mean was observed for the broad base ridge of $22.5 \mathrm{~m}$, while surface drainage was inferior to all treatments. The overall mean of this evaluation was similar to that found by Barzotto et al. (2016), who evaluated different supplementary irrigation depths in highlands for the cultivar BMX Ativa RR and reached maximum values of $4.75 \mathrm{~m}^{2} \mathrm{~m}^{-2}$ at the $\mathrm{R} 2$ stage. The leaf area index was similar although the evaluations were performed at different stages, indicating the satisfactory development of these plants in the 2015/2016 growing season.

Still, in the 2015/2016 season and at the R3 stage, the broad base ridges of 15.0 and $7.5 \mathrm{~m}$ were superior to those of $22.5 \mathrm{~m}$ and surface drainage. The maximum values of the leaf area index were found in this evaluation. These values exceed those observed by Zanon et al. (2015), who evaluated the behavior of the leaf area index in cultivar BMX Potência RR and found maximum values of $6.8 \mathrm{~m}^{2} \mathrm{~m}^{-2}$.

In the last evaluation of the 2015/2016 crop, carried out at the R5 stage, there was no significant difference between drainage techniques and cultivars. However, a reduction in the leaf area index was observed due to the proximity of the end of the cycle. Thus, comparing both growing seasons, it is observed an irregularity of precipitation that occurred in the 2014/2015 season and a lower plant population than the 2015/2016 season.

The results of plant height are shown in Table 3 . Significant differences were observed between drainage methods in the 2014/2015 season at the V9, R3, R5, and R8 stages. Broad base ridges of 15.0 and $7.5 \mathrm{~m}$ showed a superior performance at the V9 and R3 stages. The evaluation carried out at the R5 stage showed that all broad base ridges were superior to the surface drainage. The broad base ridge of $7.5 \mathrm{~m}$ was superior to the others at the phenological stage R8. Broad base ridges of 15.0 and 22.5 $\mathrm{m}$ were placed at the intermediate position, while surface drainage was inferior to the other treatments. These results are inferior to those observed by Santos et al. (2014), who found mean values of plant height of $86 \mathrm{~cm}$ over 14 growing seasons. Again, there is the occurrence of damage resulting from precipitations below the climatological normal in the $2014 / 2015$ season. In addition, we should consider that the lower plant height might have been the result of the lower plant population used in the 2014/2015 growing season. This fact did not occur in the 2015/2016 season because the plant population was high and provided a high plant height.

A significant difference was observed between cultivars in the 2014/2015 season for the V3, V9, and R3 stages, in which BMX Potência RR was superior compared to TEC IRGA 6070 RR.

TABLE 3. Plant height $(\mathrm{cm})$ at different phenological stages as a function of drainage techniques and soybean cultivars in the 2014/15 and 2015/2016 growing seasons, São João do Polêsine, RS, Brazil.

\begin{tabular}{|c|c|c|c|c|c|c|}
\hline Treatment & V3 & V9 & R1 & R3 & R5 & $\mathrm{R} 8$ \\
\hline & \multicolumn{6}{|c|}{$2014 / 2015$ growing season } \\
\hline Surface drainage & $22.15 \mathrm{a}$ & $32.93 \mathrm{a}$ & $43.33 \mathrm{a}$ & $40.48 \mathrm{~b}$ & $40.21 \mathrm{~b}$ & $42.64 \mathrm{c}$ \\
\hline Broad base ridge of $22.5 \mathrm{~m}$ & $23.69 \mathrm{a}$ & $36.73 \mathrm{a}$ & $50.31 \mathrm{a}$ & $52.13 \mathrm{~b}$ & $53.04 \mathrm{a}$ & $56.34 \mathrm{~b}$ \\
\hline Broad base ridge of $15 \mathrm{~m}$ & $22.85 \mathrm{a}$ & $43.53 \mathrm{~b}$ & $62.43 \mathrm{a}$ & $65.65 \mathrm{a}$ & $64.92 \mathrm{a}$ & $61.5 \mathrm{~b}$ \\
\hline Broad base ridge of $7.5 \mathrm{~m}$ & $24.43 \mathrm{a}$ & $45.51 \mathrm{~b}$ & $58.13 \mathrm{a}$ & $59.30 \mathrm{a}$ & $57.69 \mathrm{a}$ & $71.88 \mathrm{a}$ \\
\hline $\mathrm{CV}(\%)$ & 12.39 & 21.01 & 23.39 & 19.27 & 23.85 & 13.43 \\
\hline BMX Potência RR & $24.99 \mathrm{a}$ & $41.94 \mathrm{a}$ & $57.99 \mathrm{a}$ & $59.68 \mathrm{a}$ & $54.89 \mathrm{a}$ & $61.43 \mathrm{a}$ \\
\hline TEC IRGA 6070 RR & $21.57 \mathrm{~b}$ & $37.4 \mathrm{~b}$ & $49.11 \mathrm{a}$ & $49.11 \mathrm{~b}$ & $53.04 \mathrm{a}$ & $54.75 \mathrm{a}$ \\
\hline $\mathrm{CV}(\%)$ & 8.87 & 6.57 & 22.47 & 14.22 & 27.01 & 16.48 \\
\hline \multirow[t]{2}{*}{ Overall mean } & 23.28 & 39.67 & 53.55 & 64.39 & 53.97 & 58.09 \\
\hline & \multicolumn{6}{|c|}{ 2015/2016 growing season } \\
\hline Surface drainage & $26.45 \mathrm{~b}$ & $43.75 \mathrm{~b}$ & $60.17 \mathrm{~b}$ & $85.98 \mathrm{~b}$ & $92.13 \mathrm{~b}$ & $86.85 \mathrm{c}$ \\
\hline Broad base ridge of $22.5 \mathrm{~m}$ & $26.81 \mathrm{~b}$ & $47.96 \mathrm{a}$ & $65.8 \mathrm{~b}$ & $92.98 \mathrm{~b}$ & $87.81 \mathrm{~b}$ & $91.68 \mathrm{~b}$ \\
\hline Broad base ridge of $15 \mathrm{~m}$ & $31.25 \mathrm{a}$ & $49.25 \mathrm{a}$ & $73.03 \mathrm{a}$ & $100.26 \mathrm{a}$ & $99.06 \mathrm{a}$ & $96.41 \mathrm{a}$ \\
\hline Broad base ridge of $7.5 \mathrm{~m}$ & $31.79 \mathrm{a}$ & $50.52 \mathrm{a}$ & $73.34 \mathrm{a}$ & $101.34 \mathrm{a}$ & $102.50 \mathrm{a}$ & $97.81 \mathrm{a}$ \\
\hline $\mathrm{CV}(\%)$ & 7.45 & 5.57 & 8.38 & 6.57 & 6.71 & 4.38 \\
\hline BMX Potência RR & $30.9 \mathrm{a}$ & $50.62 \mathrm{a}$ & $65.38 \mathrm{a}$ & $99.26 \mathrm{a}$ & $96.63 \mathrm{a}$ & $95.20 \mathrm{a}$ \\
\hline TEC IRGA 6070 RR & $27.25 \mathrm{~b}$ & $45.11 \mathrm{~b}$ & $70.79 \mathrm{a}$ & $91.26 \mathrm{a}$ & $94.12 \mathrm{a}$ & $91.17 \mathrm{a}$ \\
\hline $\mathrm{CV}(\%)$ & 9.65 & 6.84 & 7.06 & 3.44 & 8.62 & 1.87 \\
\hline Overall mean & 29.08 & 47.87 & 68.08 & 95.14 & 95.37 & 93.19 \\
\hline
\end{tabular}

Means followed by the same letter in the column do not differ from each other by the Scott-Knott test at $5 \%$ significance. 
In the 2015/16 growing season, all evaluations showed significant differences between drainage methods. In the first evaluation, carried out at the V 3 stage, broad base ridges of 15 and $7.5 \mathrm{~m}$ were considered superior to that of $22.5 \mathrm{~m}$ and surface drainage. The three broad base ridges $(7.5,15.0$, and $22.5 \mathrm{~m})$ were superior to surface drainage at the V9 stage.

At the R1, R3, and R5 stages, broad base ridges of 15.0 and $7.5 \mathrm{~m}$ were superior to that of $22.5 \mathrm{~m}$ and surface drainage. In the R8 stage, broad base ridges of 15 and $7.5 \mathrm{~m}$ were superior, followed by the broad base ridge of $22.5 \mathrm{~m}$ and surface drainage. Similar results were observed by Mukhtar et al. (1990), who stated that the intensity of damage caused by excess water is influenced according to the duration and moment of soil saturation during plant growth.
Among the cultivars in the 2015/2016 growing season, the V3 and V9 stages showed significant differences for plant height. Both evaluations showed that BMX Potência RR was superior to TEC IRGA 6070 RR. These mean values of plant height can be considered low compared to other studies. Schwerz et al. (2016) evaluated different sowing times and observed a reduction in plant height when sowing was carried out in the late seasons. This situation also occurred in the 2014/15 season. Mukhtar et al. (1990) also observed that corn plants exposed to water excess at the initial vegetative stages had the lowest plant heights.

Table 4 shows the results for the shoot dry matter of the 2014/2015 and 2015/2016 seasons. No significant difference was observed between drainage methods during the five initial evaluations of plant development carried out in the 2014/2015 season.

TABLE 4. Shoot dry matter $\left(\mathrm{g}\right.$ plant $\left.{ }^{-1}\right)$ at different phenological stages according to drainage techniques and soybean cultivars in the 2014/15 and 2015/2016 growing seasons, São João do Polêsine, RS, Brazil.

\begin{tabular}{ccccccc}
\hline Treatment & V3 & V9 & R1 & R3 & R5 & R8 \\
\hline Surface drainage & \multicolumn{7}{c}{$2014 / 2015$ growing season } & & \\
\cline { 2 - 6 } Broad base ridge of $22.5 \mathrm{~m}$ & $0.68 \mathrm{a}$ & $6.13 \mathrm{a}$ & $7.52 \mathrm{a}$ & $12.03 \mathrm{a}$ & $21.45 \mathrm{a}$ & $18.28 \mathrm{c}$ \\
Broad base ridge of $15 \mathrm{~m}$ & $1.02 \mathrm{a}$ & $7.75 \mathrm{a}$ & $9.75 \mathrm{a}$ & $17.89 \mathrm{a}$ & $23.34 \mathrm{a}$ & $22.62 \mathrm{~b}$ \\
Broad base ridge of $7.5 \mathrm{~m}$ & $1.07 \mathrm{a}$ & $7.81 \mathrm{a}$ & $18.67 \mathrm{a}$ & $25.31 \mathrm{a}$ & $32.16 \mathrm{a}$ & $24.2 \mathrm{~b}$ \\
CV (\%) & $20.55^{*}$ & $12.11 *$ & $37.15 *$ & $22.15 \mathrm{a}$ & $25.49 \mathrm{a}$ & $31.22 \mathrm{a}$ \\
BMX Potência RR & $0.94 \mathrm{a}$ & $7.44 \mathrm{a}$ & $12.68 \mathrm{a}$ & $21.55 \mathrm{a}$ & $26.49 \mathrm{a}$ & $26.36 \mathrm{a}$ \\
TEC IRGA 6070 RR & $0.85 \mathrm{a}$ & 7.17 & $12.62 \mathrm{a}$ & $17.14 \mathrm{a}$ & $24.73 \mathrm{a}$ & $21.8 \mathrm{a}$ \\
CV (\%) & $9.0 *$ & $15.54 *$ & $15.22 *$ & $15.9 *$ & $15.9 *$ & $9.55^{*}$ \\
Overall mean & 0.85 & 7.31 & 12.65 & 19.34 & 25.61 & 24.08 \\
\hline & & & $2015 / 2016$ growing season & & \\
Surface drainage & $0.77 \mathrm{~b}$ & $3.34 \mathrm{~b}$ & $10.01 \mathrm{a}$ & $22.70 \mathrm{a}$ & $26.8 \mathrm{a}$ & $25.61 \mathrm{~b}$ \\
Broad base ridge of 22.5 m & $0.82 \mathrm{~b}$ & $3.79 \mathrm{~b}$ & $12.70 \mathrm{a}$ & $23.07 \mathrm{a}$ & $27.01 \mathrm{a}$ & $29.51 \mathrm{a}$ \\
Broad base ridge of 15 m & $0.97 \mathrm{a}$ & $4.05 \mathrm{~b}$ & $13.64 \mathrm{a}$ & $25.12 \mathrm{a}$ & $26.98 \mathrm{a}$ & $31.99 \mathrm{a}$ \\
Broad base ridge of 7.5 m & $1.05 \mathrm{a}$ & $4.96 \mathrm{a}$ & $16.43 \mathrm{a}$ & $25.39 \mathrm{a}$ & $29.69 \mathrm{a}$ & $33.06 \mathrm{a}$ \\
CV (\%) & 18.28 & 16.83 & $26.34 *$ & $23.96 *$ & $6.58 *$ & 11.41 \\
BMX Potência RR & $0.87 \mathrm{a}$ & $4.19 \mathrm{a}$ & $13.35 \mathrm{a}$ & $23.70 \mathrm{a}$ & $25.94 \mathrm{a}$ & $30.17 \mathrm{a}$ \\
TEC IRGA 6070 RR & $0.94 \mathrm{a}$ & $3.88 \mathrm{a}$ & $13.04 \mathrm{a}$ & $24.44 \mathrm{a}$ & $29.29 \mathrm{a}$ & $29.92 \mathrm{a}$ \\
CV (\%) & 23.66 & 19.19 & $12.31 *$ & $21.8 *$ & 10.29 & 3.90 \\
Overall mean & 0.90 & 4.04 & 13.20 & 24.07 & 27.62 & 30.04 \\
\hline
\end{tabular}

Means followed by the same letter in the column do not differ from each other by the Scott-Knott test at $5 \%$ significance. *Data transformed.

Only the R8 stage in the 2014/2015 season presented a difference between drainage methods, demonstrating that the superior treatment was the broad base ridger of $7.5 \mathrm{~m}$. Broad base ridges of 15.0 and $22.5 \mathrm{~m}$ presented a median performance compared to the others, while surface drainage was inferior to the other drainage techniques for this response variable. Regarding cultivars, no difference was observed in any of the evaluations performed for shoot dry matter in the 2014/2015 season. This result indicates that both cultivars showed similar behavior under the conditions in which the study was performed. Barzotto et al. (2015) evaluated different supplementary irrigation depths in highlands and observed shoot dry matter values of $924.9 \mathrm{~g}$ $\mathrm{m}^{-2}$ in the control treatment, which did not receive supplemental irrigation. Thus, transforming the highest value obtained from the broad base ridge of $7.5 \mathrm{~m}$, and the lowest observed value in the surface drainage for the same work unit mentioned above, values of 561.9 and $329 \mathrm{~g} \mathrm{~m}^{-2}$ were obtained, respectively. When these results are compared to those obtained, an inferiority of the highest and lowest results of the 2014/2015 season could be found in relation to the control of the study mentioned above, which did not receive supplementary irrigation, besides the fact that the leaf area index was inferior compared to that study. Plant development might have been influenced by precipitation events above and below the climatological normal. The effect of drainage methods is also noteworthy, standing out the broad base ridge of $7.5 \mathrm{~m}$.

The evaluations carried out in the 2015/16 growing season at the V3, V9, and R8 stages showed differences 
between drainage methods. In the first evaluation of the phenological stage V3, broad base ridges of 15 and $7.5 \mathrm{~m}$ accumulated higher values of shoot dry matter than those of $22.5 \mathrm{~m}$ and surface drainage. According to Thomas \& Lange (2014), plants at the initial growth stages should not undergo stress because production components are determined at this stage.

The evaluation carried out at the V9 stage in the $2015 / 2016$ season showed that only the broad base ridge of $7.5 \mathrm{~m}$ was classified as superior to the other drainage methods. In this sense, Lanza et al. (2013) stated that flood tolerance is influenced by intensity, stress duration, and soil type.

In the last evaluation of the $2015 / 2016$ season, carried out at the R8 stage, the surface drainage was inferior compared to broad base ridges. The values shown by broad base ridges were close to those observed by Perini et al. (2012), who obtained dry matter values of 34.18 g plant $^{-1}$ using the cultivar BMX Potência RR in Londrina, PR, Brazil. Considering that the results of Perini et al. (2012) were obtained in highlands, we can infer that the results presented in the present study are excellent.

Cultivars showed no statistical difference during all crop development. Thus, the cultivars TEC IRGA 6070 RR and BMX Potência RR are equivalent regarding shoot dry matter production.
The dry matter presented a mean value at harvest time in the 2014/15 growing season below that of the $2015 / 16$ season. It is due to the period of water scarcity during crop development. Analyzing the drainage methods in both growing seasons, surface drainage can be considered inferior to the others.

A difference was observed for the broad base ridges of 15 and $22.5 \mathrm{~m}$ in both seasons. In the 2014/2015 season, they presented equivalent performance, but inferior to the broad base ridge of $7.5 \mathrm{~m}$. However, in the 2015/2016 season, the three ridges $(7.5,15.0$, and $22.5 \mathrm{~m})$ were similar to each other and superior to surface drainage. This result is similar to that found by Skaggs et al. (1994), who stated that the purpose of the drainage system is to provide the nonoccurrence of water excess in the plant root system and enable conditions to perform crop management from sowing to harvest.

The harvest indices of the 2014/2015 and 2015/2016 growing seasons are shown in Table 5. No significant differences were observed between drainage methods and soybean cultivars in the $2014 / 2015$ seasons. The overall mean of treatments regarding the harvest index of this season was 0.443 . A similar result was obtained by Balbinot Junior et al. (2015), who evaluated cross and uncross soybean sowing of the cultivar BMX Potência RR and found harvest index values of 0.44 in both treatments.

TABLE 5. Harvest index as a function of drainage techniques and soybean cultivars in the 2014/15 and 2015/2016 growing seasons, São João do Polêsine, RS, Brazil.

\begin{tabular}{|c|c|c|c|c|}
\hline Treatment & \multicolumn{2}{|c|}{$2014 / 15$ season } & \multicolumn{2}{|c|}{ 2015/16 season } \\
\hline Surface drainage & 0.437 & $\mathrm{a}$ & 0.534 & A \\
\hline Broad base ridge of $22.5 \mathrm{~m}$ & 0.442 & $\mathrm{a}$ & 0.529 & A \\
\hline Broad base ridge of $15 \mathrm{~m}$ & 0.433 & $\mathrm{a}$ & 0.506 & $\mathrm{~A}$ \\
\hline Broad base ridge of $7.5 \mathrm{~m}$ & 0.460 & $\mathrm{a}$ & 0.486 & A \\
\hline $\mathrm{CV}(\%)$ & 9.49 & & 6.23 & \\
\hline TEC IRGA 6070 RR & 0.439 & $\mathrm{a}$ & 0.524 & A \\
\hline BMX Potência RR & 0.447 & $\mathrm{a}$ & 0.503 & A \\
\hline $\mathrm{CV}(\%)$ & 5.18 & & 5.46 & \\
\hline Overall mean & 0.443 & & 0.514 & \\
\hline
\end{tabular}

Means followed by the same letter in the column do not differ from each other by the Scott-Knott test at $5 \%$ significance.

The same situation observed in the 2015/2016 season occurred in the previous crop, in which both drainage techniques and soybean cultivars were not statistically different. The overall mean harvest index of the $2015 / 2016$ growing season reached 0.514 . Franchini et al. (2015) evaluated the performance of soybean sown after Urochloa ruziziensis cultivation under different pasture heights and obtained harvest indices between 0.48 and 0.50 .

Thus, when comparing the values of both seasons, the 2015/2016 season has an advantage over 2014/2015, probably due to more extended periods of precipitation below the climatological normal. Also, the different plant populations used in both seasons should be considered. In this sense, Procópio et al. (2013) evaluated different sowing densities and obtained harvest indices of 0.48 and 0.46 at sowing densities of 30.4 and 45.5 for the cultivar BRS $359 \mathrm{RR}$. These results are inverse to those observed in the present study. However, because the cultivar and sowing density are different from those used in this study, the irregular precipitation regime of the 2014/2015 season was more influential. Thus, the phenomenon that caused the lowest harvest index values in the 2014/2015 season is correlated to precipitation periods below the climatological normal, which was not so expressive in the 2015/2016 growing season.

\section{CONCLUSIONS}

The results indicate that the broad base ridges were superior to surface drainage in both seasons.

Cultivars showed no significant differences between them over the two years of study and could be recommended for cultivation in lowlands.

The broad base ridge of $7.5 \mathrm{~m}$ is recommended for soybean cultivation in lowlands as a substitute for surface drainage. 


\section{REFERENCES}

Alvares CA, Stape JL, Sentelhas PC, Gonçalves JL de M, Sparovek G (2013) Köppen's climate classification map for Brazil. Meteorologische Zeitschrift 22:711-728.

Alves JD, Magalhães MM, Goulart PFP, Dantas BF, De Gouvêa JÁ, Purcino RP, Magalhães PC, Fries DD, Do Livramento DE, Meyer LE, Seiffert M, Silveira T (2002) Mecanismos de tolerância da variedade de milho "saracura" (brs 4154) ao alagamento. Revista Brasileira de Milho e Sorgo 1(1):41-52.

Balbinot Junior AA, Procópio SO, Costa JM, Kosinski CL, Panison F, Debiasi H, Franchini JC (2015) Espaçamento reduzido e plantio cruzado associados a diferentes densidades de plantas em soja. Semina: Ciências Agrárias 36(5):2977-2986.

Bamberg AL, Pauletto EA, Gomes AS, Timm LC, Pinto LFS, Lima ACR, Silva TR (2009) Densidade de um Planossolo sob sistemas de cultivo avaliada por meio da tomografia computadorizada de raios gama. Revista Brasileira de Ciência do Solo 33:1079-1086.

Barzotto F, Robaina AD, Peiter MX, Torres RR, Kirchner JH, Rosso RB, Girardi LB, Mezzomo W (2016)

Efeito da irrigação e da adubação nitrogenada nos parâmetros de desenvolvimento e nos componentes de produção da cultura da soja. Revista Espacios 37(21):10.

Bortoluzzi MP, Heldwein AB, Trentin R, Lucas DDP, Righi EZ, Leonardi M (2017) Risk of water surplus in soybean crop on haplic planosol soil in the Central Depression of Rio Grande do Sul State, Brazil. Ciência Rural 47(2):1-7. DOI: http://dx.doi.org/10.1590/0103$8478 \mathrm{cr} 20160170$

Duarte SN, Silva ÊF de F, Miranda JH de, Medeiros JF de, Costa RNT, Gheyi HR (2015) Fundamentos de drenagem agrícola, Instituto Nacional de Ciência e Tecnologia em Salinidade, $356 \mathrm{p}$.

Franchini JC, Balbinot Junior AA, Debiasi H, Conte O, (2015) Desempenho da soja em consequência de manejo de pastagem, época de dessecação e adubação nitrogenada. Pesquisa Agropecuária Brasileira 50(12):1131-1138. DOI: 10.1590/S0100-204X2015001200002

Fehr WR, Caviness CE (1977) Stages of soybean development. Ames: State University of Science and Technology, p. 11p.

Ferreira DF (2011) Sisvar: a computer statistical analysis system. Ciência e Agrotecnologia 35(6):1039-1042. DOI: http://dx.doi.org/10.1590/S1413-70542011000600001

Fiorin TT, Spohr RB, Carlesso R, Michelon CJ, Santa CD, David G de (2009) Produção de silagem de milho sobre camalhões em solos de várzea. Revista Pesquisa Aplicada \& Agrotecnologia 2(1)148-153.

Instituto Rio Grandense do Arroz (2019) Boletim de resultados da lavoura - Safra 2018/19 - Arroz irrigado e soja em rotação. Available: https://irgaadmin.rs.gov.br/upload/arquivos/201909/05171808relatorio-da-safra-2018-19-31-agosto-2019.pdf. Accessed: Oct 15, 2019.
Klamt E, Dalmolin RSD, Cabral D da R (1997) Solos do município de São João do Polêsine: Características, classificação, distribuição geográfica e aptidão de uso. Santa Maria, UFSM, 93p.

Lanza LNM, Rossi SC, Sodek L (2013) Adubação nitrogenada beneficia soja alagada. Bragantia 72(1):2-9.

Missio EL, Rubin S de AL, Gabe NL, Ozelame JG (2010) Desempenho de genótipos de soja em solo hidromórfico de várzea. Pesquisa Agropecuária Gaúcha 16(1):23-29.

Mukhtar S, Kanwar RS, Baker JL (1990) Corn Grown as Affected by Excess Soil Water. Agricultural and Biosystems Engineering 33(22).

Oliveira ACB, Da Rosa APA (2014) Indicações técnicas para a cultura da soja no Rio Grande do Sul e em Santa Catarina, safras 2014/2015 e 2015/2016. Pelotas, EMBRAPA Clima Temperado. (Documento 382)

Perini LJ, Fonseca Júnior N da S, Destro D, Prete CEC, (2012) Componentes da produção em cultivares de soja com crescimento determinado e indeterminado. Semina: Ciências Agrárias 33(1):2531-2544. DOI: http://dx.doi.org/10.5433/1679-0359.2012v33n6Supl1p 2531

Procópio S de O, Balbinot Junior AA, Debiasi H, Franchini JC, Panison F (2013) Plantio cruzado na cultura da soja utilizando uma cultivar de hábito de crescimento indeterminado. Revista de Ciências Agrarias 56(4):319325. DOI: http://dx.doi.org/10.4322/rca.2013.048

Richter GL, Zanon Júnior A, Streck NA, Guedes JVC, Kräulich B, Da Rocha TSM, Winck JEM, Cera JC (2014) Estimativa da área de folhas de cultivares antigas e modernas de soja por método não destrutivo. Bragantia 73(4):416-425. DOI: http://dx.doi.org/10.1590/16784499.0179

Santos HP dos, Fontaneli RS, Pires J, Lampert EA, Vargas AM, Verdi AC (2014) Rendimento de grãos e características agronômicas de soja em função de pastagens perenes em sistema de plantio direto. Bragantia 14(3):319-326. DOI: http://dx.doi.org/10.1590/16784499.0136

Sartori GMS, Marchesan E, De David R, Carlesso R, Petry MT, Donato G, Cargnelutti Filho A, Da Silva MF (2015) Rendimento de grãos de soja em função de sistemas de plantio e irrigação por superfície em Planossolos. Pesquisa Agropecuária Brasileira 50(12):1139-1149. DOI: http://dx.doi.org/10.1590/S0100-204X2015001200003

Silva CAS da, Parfitt JMB (2004) Drenagem Superficial para Diversificação do Uso dos Solos de Várzea do Rio Grande do Sul. Pelotas, Embrapa Clima Temperado. (Circular técnica)

Silva JJC da, Raupp AA, Silva CAS da, Theisen G (2006) Camalhões de base larga: Uma opção para drenagem superficial de várzeas muito planas na região costeira do Rio Grande do Sul. Pelotas, Embrapa Clima Temperado, 8p.(Circular técnica 56)

Schwerz F, Caron BO, Elli EF, De Souza VQ, De Oliveira DM, Rockenbach AP (2016) Soybean morphological and productive characteristics influenced by meteorological parameters and sowing dates. Científica, Jaboticabal, 44(2):121-130. 
Skaggs RW, Brevé MA, Gilliam JW (1994) Hydrologic and water quality impacts of agricultural drainage. Critical Reviews in Environmental Science and Technology 24(1):1-32.

SOSBAI - Sociedade Sul-Brasileira de Arroz Irrigado (2012) Recomendações técnicas da pesquisa para o Sul do Brasil. In: 29a Reunião Técnica da Cultura do Arroz Irrigado. Gravatal, RS, SOSBAI, Anais...
Thomas AL, Lange CE (2014) Soja em solos de várzea do Sul do Brasil. Porto Alegre, Evangraf, 128 p.

Zanon AJ, Streck NA; Richter GL, Becker CB, Da Rocha TSM, Cera JC, Winck JEM, Cardoso ÂP, Tagliapietra EL, Weber PS (2015) Contribuição das ramificações e a evolução do índice de área foliar em cultivares modernas de soja. Bragantia 74(3):279-290. DOI:

http://dx.doi.org/10.1590/1678-4499.0463 